\title{
MRI findings in endophthalmitis and panophthalmitis
}

\author{
Vikash Sharma, ${ }^{1}$ Rajaram Sharma 다 , ${ }^{1,2}$ Tapendra Tiwari, ${ }^{1}$ Saurabh Goyal ${ }^{1}$
}

\begin{abstract}
${ }^{1}$ Department of Radio-diagnosis, Pacific Institute of Medical Sciences Umarda Campus, Udaipur, India

${ }^{2}$ Department of Radio-diagnosis, Seth GS Medical College and KEM Hospital, Mumbai, India
\end{abstract}

\section{Correspondence to} Dr Rajaram Sharma; hemantgalaria13@gmail.com

Accepted 30 January 2022
Check for updates

(C) BMJ Publishing Group Limited 2022. No commercial re-use. See rights and permissions. Published by BMJ.

To cite: Sharma V, Sharma R,
Tiwari T, et al. BMJ Case
Rep 2022;15:e246856.
doi:10.1136/bcr-2021-
246856

\section{DESCRIPTION}

Endophthalmitis is an inflammation of the eyeball without the involvement of the sclera and involvement of the sclera makes the diagnosis panophthalmitis. Endophthalmitis can occur exogenously, usually after ophthalmic surgery, post-traumatically or endogenously. Endogenous bacterial endophthalmitis is a severe and emergency condition that develops when bacteria cross the blood-ocular barrier and multiply inside the deep structures of the eye, such as the vitreous and aqueous chambers. Endophthalmitis is the most common complication after cataract surgery. Regardless of aetiology, endophthalmitis usually causes vision loss. ${ }^{1}$ Severe posterior and anterior segments inflammation are frequently associated with scleral abscess, corneal opacity and perforation or rupture in panophthalmitis.

MRI with diffusion-weighted imaging (DWI) helps further assess complications, disease extent and response to therapy, especially when ophthalmoscopic visualisation is obscured by lens opacification. $^{2}$

Here, we discuss an elderly male patient who came to our hospital with complaints of complete loss of vision, unable to open eyes, blood discharge from the right eye, purulent discharge from the left eye and severe pain in both eyes for the last 10 days. On examination, both eyes were swollen, extensive eyelid oedema and erythema, and proptosis of both eyes, the right eye appeared red, and the left eye revealed a darkened anterior chamber. $\mathrm{He}$ had a history of right eye cataract surgery before 7 months. After surgery, he developed pain and

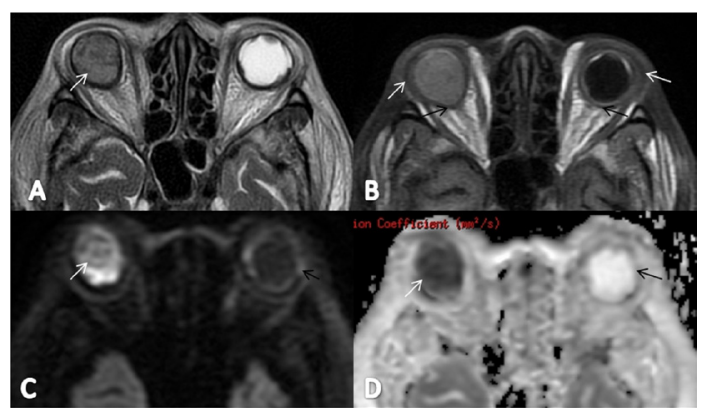

Figure 1 MRI of bilateral orbits in the axial plane; (A) Restricted diffusion is observed in right eye globe on DWI (white arrow) and subretinal space of left globe (black arrow), which corresponds to an area of low apparent diffusion coefficient (ADC) value, (B) Representing exudates/pus, (C)T2W image showing a deformed right globe with a vitreous collection (white arrow) and (D) Axial T1WI demonstrates bilateral retro-orbital fat stranding (white arrow) and exudative vitreoretinal detachments (black arrow).

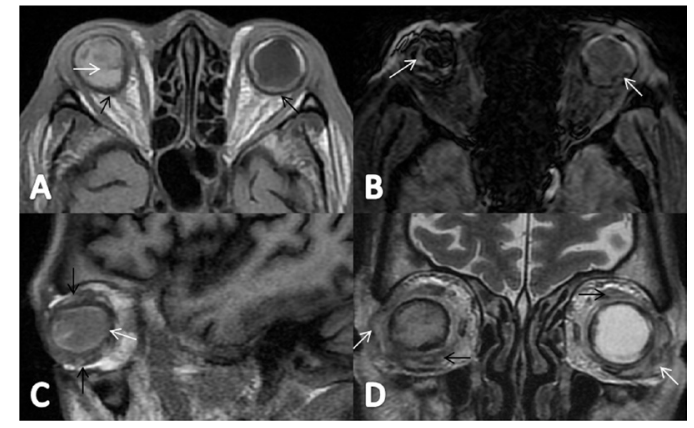

Figure 2 MRI of right panophthalmitis and left endophthalmitis: (A) T2W coronal plane image demonstrates differential signal intensities in bilateral globes extensive peribulbar fat stranding (white arrow) and extraocular muscle swelling,(black arrow) (B) Axial FLAIR image depicting hyperintense signal in the right globe (white arrow), vitreal exudates, with bilateral retinal detachment (black arrow), (C) Blooming artefacts are illustrated in bilateral orbits (white arrows) on SWI image representing blood degradation products and (D) T2W sagittal plane image showing a subretinal collection, irregular scleral thickening, retinal detachment, (white arrow) edematous periorbital soft tissues in the right orbit (black arrow). FLAIR, Fluid-attenuated inversion recovery; SWI, Susceptibility weighted imaging.

congestion in both eyes. He also had a history of uncontrolled diabetes and hypertension. As the patient was unable to open his eyes and was very apprehensive to the pain, the ophthalmologist could not fully examine the eyes. The patient underwent an MRI of both orbits under a mild sedation to evaluate his orbital symptoms and to assess for the optic nerve status. The MRI demonstrated that the right globe was deformed with irregular margins, and hypo to mixed-signal was observed within the vitreous (figure $1 \mathrm{~A}, \mathrm{~B}$ and figure $2 \mathrm{~A}$ ), showing patchy restricted diffusion on DWI and blooming on susceptibility-weighted images representing pus collections (figure 1C,D and figure $2 \mathrm{~B}$ ). The right eye had a subretinal collection, exudative vitreoretinal detachment and deformed iris (figure 2C). Similar imaging features were also seen within the extraconal and intraconal compartments of the left orbit. The retro-orbital fat looked dirty on MRI sequences, and these signal abnormalities extended till the orbital apex (figure 2D). Bilateral optic nerves appeared thickened with altered signal intensities representing the optic neuritis. The MRI also precisely depicted soft tissue involvement in the preseptal and postseptal compartment of orbits extending along the zygomatic, maxillary regions bilaterally. The patient was advised for evisceration of the eyes, which he declined. Presently he is 
being managed on antibiotics; however, his overall condition is deteriorating.

MRI findings of panophthalmitis and endophthalmitis are scarcely available in the literature. Here, we have discussed the spectrum of imaging findings of endophthalmitis and

\section{Patient's perspective}

I was operated for the cataract and was recovering well. Few months later, I had started feeling severe pain in my both eyes with pus and reddish discharge. Then I went to the hospital for a check-up and by that time the pain became intolerable and I also lost my vision. After considering my situation doctor advised an MRI. MRI report showed some serious diagnosis and advised removal of the eye balls, but I refused for the same. Currently I am on medications and hoping for a good outcome. panophthalmitis. Other orbital non-infectious inflammatory diseases can show similar findings on MRI; however, DWI supports identify infectious exudates/pus and monitor response to therapy. Familiarity of the spectrum of imaging findings of panophthalmitis and endophthalmitis is essential for radiologists and helps in disease management. ${ }^{2}$

Contributors VS and RS contributed to the planning, conduct, reporting, conception and design, acquisition of data or analysis and interpretation of data. TT and SG contributed to the acquisition of data and interpretation of data.

Funding The authors have not declared a specific grant for this research from any funding agency in the public, commercial or not-for-profit sectors.

Competing interests None declared.

Patient consent for publication Consent obtained from parent(s)/guardian(s).

Provenance and peer review Not commissioned; externally peer reviewed.

Case reports provide a valuable learning resource for the scientific community and can indicate areas of interest for future research. They should not be used in isolation to guide treatment choices or public health policy.

\section{ORCID iD}

Rajaram Sharma http://orcid.org/0000-0003-1126-5875

\section{REFERENCES}

1 Chen K-J, Chen Y-P, Chao A-N, et al. Prevention of evisceration or enucleation in endogenous bacterial panophthalmitis with no light perception and scleral abscess. PLoS One 2017;12:e0169603.

2 Radhakrishnan R, Cornelius R, Cunnane MB, et al. Mr imaging findings of endophthalmitis. Neuroradiol J 2016;29:122-9.

Copyright 2022 BMJ Publishing Group. All rights reserved. For permission to reuse any of this content visit

https://www.bmj.com/company/products-services/rights-and-licensing/permissions/

BMJ Case Report Fellows may re-use this article for personal use and teaching without any further permission.

Become a Fellow of BMJ Case Reports today and you can:

- Submit as many cases as you like

- Enjoy fast sympathetic peer review and rapid publication of accepted articles

- Access all the published articles

Re-use any of the published material for personal use and teaching without further permission

\section{Customer Service}

If you have any further queries about your subscription, please contact our customer services team on +44 (0) 2071111105 or via email at support@bmj.com.

Visit casereports.bmj.com for more articles like this and to become a Fellow 